EDITORIAL

\title{
Horticulture and Ornamental Horticulture
}

\author{
PATRÍCIA DUARTE DE OLIVEIRA PAIVA*
}

Horticulture is a segment of the agriculture area, whose original term comes from the latin word Hortus that means "a flower-filled meadow" or "culture of a garden". Hortus means horto (Portuguese) or garden (English) and is a term used to designate an area with fruits all year long. In contrast, in simple land, the production is seasonal whose harvest may occur only once a year.

Horticulture Science, a direct relationship between horticulture and science, may be considered as an essential life science, and involves research and education for knowledge and to establish skills on biological resources, industry, environmental enhancement, and human health. Horticulture Science area involves collection, preservation, organization, characterization and improvement of genetic resources. The application of science to horticulture is referred as Horticulture Technology (ISHS, 2017).

It is important to highlight that Horticulture is not only related with vegetable culture (as sometimes is thought), but it is a broader concept that includes a great number of species as plants for comfort and beautification. Crops involved in Horticulture are vine, perennial bush and tree nuts, vegetables (including roots, tubers, shoots, stems, leaves), fruits, flowers of edible, aromatic and medicinal plants, cut flowers, potted ornamental plants, and bedding plants, trees and shrubs, turf and ornamental grasses. Besides, since some horticultural plants are used by animals to produce secondary compounds and these compounds may be considered as a horticultural product, such as honey, raw silk (not the silk), and maple syrup. Also, mushrooms (cultivated or gathered) are considered as horticultural crops (ISHS, 2017). Horticulture can be divided in Food Horticulture and Ornamental Horticulture.

Ornamental horticulture concerns the production and use of woody and herbaceous plants (Encyclopaedia Britannica, 2017), being divided in Floriculture and Landscape Horticulture, besides Turf Industry. Floriculture can be considered as an industry which involves growers, wholesale market, activities of flower arrangement, and the retail florist, including floral products in the florist's trade. A grower varies from a small family run farm to a huge and technological production. Flower and pot plant production may occur outdoor, but since it is largely performed in greenhouses, this industry is strongly related to Horticulture.
Considering the quality and its perishability, transportation is an important segment that should avoid losses.

Ornamental Horticulture also concerns landscape and is divided into growth, design and maintenance. Environmental Horticulture or Urban Horticulture is a recent denomination associated with activities like landscaping, gardening, and arboriculture. All these issues are related with human life quality and health, which are also linked to another term, Horticultural Therapy. In order to improve the quality of life, it is important to consider in Urban Horticulture the urban and peri-urban parks, urban gardens, as well as the street trees. Arboriculture is a term used only for ornamental trees in urban spaces, not for fruit trees.

In order to give support to Floriculture and Urban Horticulture, the nursery industry plays an important role with the production and distribution of diversified plants, including herbaceous and wood ornamentals, fruit plants, some vegetables, aromatic and medicinal plants whose use have been playing an important role in gardens. Plant propagation also plays in important role in Horticulture which includes seeds, cuttings, bulbs, corms, tubers, rhizomes, and swollen roots. Nurseries also include sod farms that grow grass, cut and move to landscape projects. Many nurseries also execute garden planning (design) in addition to wholesale, retail, and mail-order operations. For example, garden centers are retail outlets that sell plants grown in nurseries, along with garden supplies.

Nowadays, Ornamental Horticulture has being considered as one of the most important scientific journal in this area.

In summary, Horticulture is a complex subject that involves different (but strongly connected) areas, that offers many opportunities for education, resources, professional industries, technology and employment.

\section{References}

Encyclopaedia Britannica. Ornamental Horticulture. Available in www.britannica.com. Access on 15th Decemer 2017

ISHS. Defining horticulture. Available in www.ishs.org. Access on 14th December 2017. 